\title{
THE DEVELOPMENT OF ONLINE LEARNING GAME ON LINEAR PROGRAM COURSES
}

\author{
Zainnur Wijayanto, Dafid Slamet Setiana, Betty Kusumaningrum* \\ Universitas Sarjanawiyata Tamansiswa, Yogyakarta, Indonesia
}

\begin{abstract}
Article Info
Article history:

Received Dec 19, 2020

Revised Jul 14, 2021

Accepted Jul 16, 2021

\section{Keywords:}

Learning Games,

Linear Programs,

Online

ABSTRACT

This study aims to produce online learning games on linear program subjects for 3rd-semester students that are valid, practical, efective and can increase student learning motivation. Students are less interested in linear program subject because it requires high analysis skill and feel boring. This research and development model consisting of the stages of define (literature study and field survey), design (early product design activities), develop (expert validation, product revisions, and development testing), and disseminate (final product revision) with descriptive analysis techniques qualitatively and quantitatively. Qualitative descriptive analysis techniques are used to describe the stages of development that describe the results of observations of the implementation and effectiveness of online learning games that have been developed in the field. Quantitative descriptive analysis techniques are used at the development stages. This study has achieved the expected goal: producing online learning games for linear program subjects that are valid (very good category), practical (very good category), and effective ( $85.71 \%$ of students had achieve a minimum score of C).
\end{abstract}

This is an open access article under the CC BY-SA license.

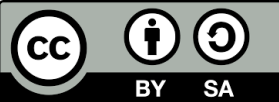

\section{Corresponding Author:}

Betty Kusumaningrum,

Department of Mathematics Education,

Universitas Sarjanawiyata Tamansiswa, Yogyakarta

Jl. Batikan, Tahunan, Umbulharjo, Daerah Istimewa Yogyakarta 55167, Indonesia

Email: betty.kusumaningrum@ustjogja.ac.id

\section{How to Cite:}

Wijayanto, Z., Setiana, D. S., \& Kusumaningrum, B. (2022). The development of online learning game on linear program courses. Infinity, 11(1), 133-144.

\section{INTRODUCTION}

The development of science and technology encourages the learning process to be more applicable and attractive as an effort to improve the quality of education (Hughes, 2004). Appropriate teaching methods will help the students understanding process, so students can apply the knowledge gained in everyday life (Ganyaupfu, 2013; Kalyani \& Rajasekaran, 2018). One of the ways to encourage the achievement of effective learning, is to use learning aids or what are commonly called media (Wahid et al., 2020; Wardani et al., 2018).

One of the media that can be used in learning is a game (Wahyudi et al., 2019). Games can be used as learning media (Becker, 2007). One of the effective learning methods 
to achieve learning goals is to use games, or the learning process through gaming (Aleksić et al., 2016; Ding et al., 2017). Gaming is one of the main methods in the learning process for adults (Hidayat, 2018). Therefore the role of the media in the learning process is important because it will make the learning process more varied and less boring (Pivec \& Kearney, 2007; Wijaya, 2020).

The use of games as learning media can be applied to technologies that are widely used today, such as mobile phones (Ekanayake \& Wishart, 2014). A mobile phone is a communication tool that can be used to make calls or send text messages. Mobile phones that are currently developing have supporting features, including internet, game applications, and others. This mobile phone can be used as a device to play mobile games (Godwin-Jones, 2011).

Implementation of games on mobile phones and internet networks as learning media at the higher education are not fully used yet (Yu \& Conway, 2012). Therefore, it is necessary to design online learning games as an innovation in mathematics learning that can increase motivation to learn mathematics in the subject that are considered difficult by students, one ofthem is a linear program. Liner program requires analysis and long processing steps (Ariawan, 2015) and also requires high reasoning and communication skills (Saparwadi \& Aini, 2016). It can be seen in the final exam, there were still many students who get C+ $(17.85 \%), \mathrm{C}(14.28 \%)$, and D (25\%) grades. By using online games, it is expected to increase student motivation which can improve student learning outcomes. The results of this study are expected to be used as a reference in developing learning media that is suitable for internet generation learning. In addition, learning games that have been designed can be used by educational institutions as a basis for improving the quality of the process and student learning outcomes. The need for more urgent references is associated with the lack of references that discuss online game development in mathematics learning at the higher education.

\section{METHOD}

\subsection{Research Design}

The procedure for developing a linear program online learning game consists of define, design, develop, and disseminate stages.The define stage includes literature study and field surveys to identify problems and analyse needs; the design stage includes early product design activities; the develop stage includes expert validation, product revisions, and development testing, while the dissemination stage includes final product revision. The development procedure are presented in Figure 1.

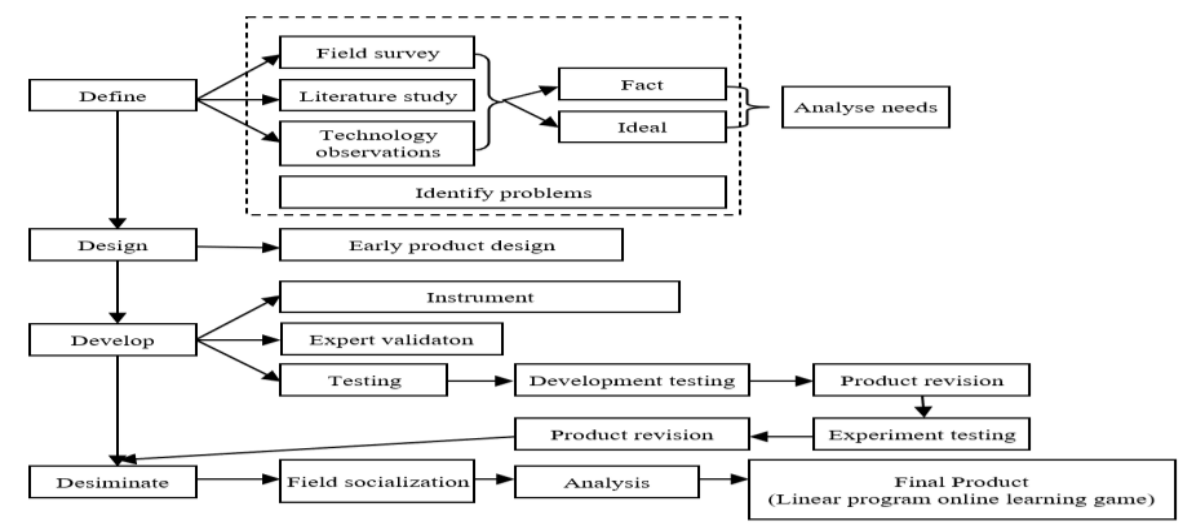

Figure 1. The Development Procedure 


\subsection{Participants}

Research subjects are grouped based on two activities: product development and product development testing. At the product development stage, research subjects consisted of 2 expertswhile at the product development testing stage, the research subjects were 28 students.

\subsection{Data Collection}

In the define stage, data was collected by observation, interviews, and literature studies to obtain information about the use of technology and the internet in learning among students; (2) the design stage: data was collected by literature study to produce linear program questions as material for making online learning games; (3) the development stage: data was collected by instrument validation (at the early product development stage), a questionnaire (at the development testing and the experiment testing) and student learning outcomes.

\subsection{Data Analysis}

The data were analysed by descriptive qualitative and quantitative. Qualitative descriptive analysis was used to describe the development implementation of linear program online learning game, and describe the effectiveness of linear program online learning games that have been developed in the field. Quantitative data analysis was used at the development stage.

The data analysis approach used was: (1) the implementation and results of the online learning game development linear program and the validity of the linear program questions described in the form of a data presentation, then analyzed qualitatively and quantitatively; (2) at the development testing, the test results of the application of the linear program online learning game were analyzed by a quantitative approach; (3) experiment testing using a quantitative analysis approach.

The following were the steps that used to determine the quality criteria for the developed game-based learning media products: (1) data in the form of expert scores obtained through the validation sheet are added up; (2) the actual total score was obtained converted into qualitative data on a scale of four shown in Table 1.

Table 1. Conversion of quantitative data to qualitative data of scale 5

\begin{tabular}{cc}
\hline Interval & Category \\
\hline $\mathrm{X}>\mathrm{Mi}+1.5 \mathrm{SBi}$ & Verry good \\
$\mathrm{Mi}+0.5 \mathrm{SBi}<\mathrm{X} \leq \mathrm{Mi}+1.5 \mathrm{SBi}$ & Good \\
$\mathrm{Mi}-0.5 \mathrm{SBi}<\mathrm{M} \leq \mathrm{Mi}+0.5 \mathrm{SBi}$ & Enough \\
$\mathrm{Mi}-1.5 \mathrm{SBi}<\mathrm{M} \leq \mathrm{Mi}-0.5 \mathrm{SBi}$ & Less \\
$\mathrm{X} \leq \mathrm{Mi}-1.5 \mathrm{SBi}$ & Verry less \\
\hline
\end{tabular}

The analysis technique for measuring validity was to provide the instruments that would be validated to the expert deemed appropriate to provide an assessment. The aspects that were assessed in term of material/content, construction, and language. The criterion used to decide that an instrument has an adequate degree of validity is if the mean $(\mathrm{X})$ of the results of the assessment for all minimum aspects is in the "valid" category. If this is not the case, it is necessary to revise it based on the suggestions of the validators or by looking back at the aspects that are lacking, re-validated then re-analyzed. And so on until it meets the minimum average value in the valid category. 
Linear program online learning game are considered practical if the results of student assessments for all minimal aspects are in the "Good" category. These results indicate that the online games developed are practical and can be applied at universities, while it can be said effective if it meets the effectiveness indicator: the achievement of student competence classically reaches the minimum category $\mathrm{C}$ (passed). The data analysis steps on the effectiveness of the linear program online learning game in terms of achieving student learning competencies were: (1) recapitulating the scores that appear automatically at the end of the game (2) calculating the (number) of students who reach the specified level of learning outcomes: minimum $\mathrm{C}$; and (3) determine the achievement of the objectives or classical learning outcomes (all students in one class): minimum $75 \%$ of students get a $\mathrm{C}$ grade.

\section{RESULTS AND DISCUSSION}

\subsection{Results}

The result of this research was a product in the form of an online learning game "Kahoot" in the Linear Program subject. Before developing a product, a needs analysis must be carried out first. Needs analysis was carried out to obtain information about linear program learning of $3^{\text {rd }}$ semester Mathematics Education students and the use of technology and internet in mathematics learning among the students.

The needs analysis obtain in this research process are linear program learning has taken advantage of technology by using Lindo software (Linear Interactive Discreat Optimizer). This software is used to solve linear program problems easily, quickly, and accurately. However, in linear program learning, internet-based technology has not been utilized, such as the use of online game-based applications that encourage motivation and interest in learning linear program. Online game applications using kahoot have never been used in linear program subject. Kahoot is a free online game-based learning platform that can be accessed via a web browser or kahoot application using a computer or gadget that is easily accessible to students.

After conducting a needs analysis, the next step was design. The first design stage in this research was a literature study that used for making questions about linear program in online learning games. The next stage was make an online learning game using kahoot. The questions were made in 2 forms, 5 multiple choice questions and 5 true and false questions. Multiple choice and true-false questions are selected based on their ability to cover a wide range of subjects in an exam.

Before making the questions, the researcher determined the question lattices first, so that the questions were in accordance with the indicators of cognitive ability to be measured. The grid of questions is presented in Table 2.

Table 2. The grid of questions

\begin{tabular}{lcc}
\hline \multicolumn{1}{c}{ Indicators } & Number & Form of problem \\
\hline $\begin{array}{l}\text { Can determine the area of the set of solutions of a known } \\
\text { system of two-variable linear inequalities }\end{array}$ & 1,2 & Multiple choice \\
$\begin{array}{l}\text { Can determine a two-variable linear inequality system from } \\
\text { the set area of known solutions in the problem }\end{array}$ & $3,4,5$ & Multiple choice \\
$\begin{array}{l}\text { Can determine the area of the set of solutions of a known } \\
\text { system of two-variable linear inequalities }\end{array}$ & 6,7 & True-False \\
$\begin{array}{l}\text { Can determine the minimum value of a function if the area of } \\
\text { the set of solutions is known }\end{array}$ & 8 & True-False \\
\hline
\end{tabular}


Indicators

Number Form of problem

Can determine the maximum revenue from a sale if the area of the set of solutions is known

Can determine the intersection point between two lines

10

True-False

The questions that have been made then validated. The purpose of validation was to find out whether the instrument could be measuring what is desired. Validation was carried out by 2 lecturers. The validation process was validating ten linear program questions in the Kahoot. The results of the question validation for each component can be seen in Table 3 .

Table 3. Results of validation

\begin{tabular}{llccc}
\hline No & \multicolumn{1}{c}{ Components } & V1 & V2 \\
\hline A. & Content & & \\
1 & Problems in accordance with the measured cognitive domain & 5 & 5 \\
2 & There is only one correct answer & 5 & 5 \\
\hline & & Total & 10 & 10 \\
\hline & & & $\mathbf{1 0}$ \\
\hline B. & Construction & 5 & 4 \\
1. & Problem is clearly formulated & 5 & 5 \\
2. & The question provides no clues to the answer & 4 & 5 \\
3. & The images/graphs/diagrams are presented clearly & 5 & 5 \\
4. & The item does not depend on the answer to the previous question & 5 & 5 \\
5. & Problem does not contain double negative statements & Total & 24 & 24 \\
\hline & & Average & $\mathbf{2 4}$ \\
\hline & & & \\
\hline C. & Language & 5 & 5 \\
1. & The language used is in accordance with Indonesian rules & 5 & 5 \\
2. & Communicative language & 5 & 5 \\
3. & No local language is spoken & Total & 15 & 15 \\
\hline & & Average & $\mathbf{1 5}$ \\
\hline
\end{tabular}

The criteria and limit values for content were determined (see Table 4).

Table 4. The Criteria and limit values of content

\begin{tabular}{lll}
\hline \multicolumn{1}{c}{ Content } & \multicolumn{1}{c}{ The criteria and limit values of content } \\
\hline The max score of each item: 5 & Very good & $\mathrm{X}>7.95$ \\
The min score of each item: 1 & Good & $6.65<\mathrm{X} \leq 7.95$ \\
Number of item: 2 & Enough & $5.35<\mathrm{X} \leq 6.65$ \\
Ideal average $=\frac{10+2}{2}=6$ & Less & $4.05<\mathrm{X} \leq 5.35$ \\
Standard deviation $=\frac{10-2}{6}=\frac{4}{3}=1.3$ & Very less & $\mathrm{X} \leq 4.05$ \\
& Average $: \mathbf{1 0}$ (Very good) & \\
\hline
\end{tabular}

The criteria and limit values for construction were determined (see Table 5). 
Table 5. The Criteria and limit values of construction

\begin{tabular}{lll}
\hline \multicolumn{1}{c}{ Construction } & \multicolumn{2}{c}{ The criteria and limit values of construction } \\
\hline The max score of each item: 5 & Very good & $\mathrm{X}>19.95$ \\
The min score of each item: 1 & Good & $16.65<\mathrm{X} \leq 19.95$ \\
Number of item: 5 & Enough & $13.35<\mathrm{X} \leq 16.65$ \\
Ideal average $=\frac{25+5}{2}=15$ & Less & $10.05<\mathrm{X} \leq 13.35$ \\
& Very less $\quad \mathrm{X} \leq 10.05$ \\
Standard deviation $=\frac{25-5}{6}=3.3$ & Average $: \mathbf{2 4}$ (Very good) \\
\hline
\end{tabular}

The criteria and limit values for language were determined (see Table 6).

Table 6. The Criteria and limit values of language

\begin{tabular}{lll}
\hline \multicolumn{1}{c}{ Language } & \multicolumn{1}{c}{ The criteria and limit values of language } \\
\hline The max score of each item: 5 & Very good & $\mathrm{X}>12$ \\
The min score of each item: 1 & Good & $10<\mathrm{X} \leq 12$ \\
Number of item: 3 & Enough & $8<\mathrm{X} \leq 10$ \\
Ideal average $=\frac{15+3}{2}=9$ & Less & $6<\mathrm{X} \leq 8$ \\
& Very less & $\mathrm{X} \leq 6$ \\
Standard deviation $=\frac{15-3}{6}=2$ & Average $: \mathbf{1 5}$ (Very good) & \\
\hline
\end{tabular}

The overall results of test validation were very good (see Table 7), so the linear program test proper to use in the Kahoot. The validator also provides suggestion: questions are formulated more clearly and the pictures/graphs are presented more clearly. The questions that have been validated are then used in the Kahoot learning game.

Table 7. Summary of test validation results

\begin{tabular}{clccc}
\hline No & & Component & Average & Criteria \\
\hline 1 & Content & 10 & Very good \\
2 & Construction & 24 & Very good \\
3 & Language & 15 & Very good \\
\hline
\end{tabular}

\section{Development Testing}

The subjects in this stage were 5 students of the Mathematics Education Study Program who have been taking linear program lectures. The students were asked to become a player in the online learning game Kahoot. The researcher simulated by showing the game using a projector and the five students were asked to take part in the game until finish using their smartphones. Then, students filled out a questionnaire and provide a suggestion on the linear program online learning game that has been made. The results of the questionnaire can be seen on Table 8 .

Table 8. Development testing result

\begin{tabular}{|c|c|c|c|c|c|c|c|}
\hline \multirow{2}{*}{\multicolumn{2}{|c|}{ Components }} & \multicolumn{5}{|c|}{ Respondents } & \multirow{2}{*}{ Total } \\
\hline & & 1 & 2 & 3 & 4 & 5 & \\
\hline \multicolumn{8}{|c|}{ Game online } \\
\hline 1 & Increase interest on linear programming & 5 & 5 & 5 & 5 & 5 & 25 \\
\hline 2 & Increase motivation to learn & 5 & 5 & 5 & 5 & 5 & 25 \\
\hline
\end{tabular}




\begin{tabular}{|c|c|c|c|c|c|c|c|}
\hline & \multirow{2}{*}{ Components } & \multicolumn{5}{|c|}{ Respondents } & \multirow{2}{*}{ Total } \\
\hline & & 1 & 2 & 3 & 4 & 5 & \\
\hline 3 & $\begin{array}{l}\text { Improve communication to exchange } \\
\text { information among studens }\end{array}$ & 5 & 5 & 5 & 5 & 5 & 25 \\
\hline 4 & $\begin{array}{l}\text { The set time duration can increase the speed and } \\
\text { accuracy in answering questions }\end{array}$ & 5 & 5 & 5 & 5 & 5 & 25 \\
\hline \multirow[t]{2}{*}{5} & Easy to use & 4 & 5 & 4 & 4 & 5 & 22 \\
\hline & & & & & \multicolumn{2}{|c|}{ Average } & 24.4 \\
\hline \multicolumn{8}{|c|}{ Appearance } \\
\hline 1 & Easy to read & 5 & 5 & 5 & 5 & 5 & 25 \\
\hline 2 & Images/graphics are presented clearly & 5 & 4 & 4 & 5 & 5 & 23 \\
\hline 3 & $\begin{array}{l}\text { The order of the questions is adjusted to the } \\
\text { difficulty level of the questions }\end{array}$ & 5 & 5 & 5 & 5 & 5 & 25 \\
\hline 4 & $\begin{array}{l}\text { The duration of answering the questions is } \\
\text { sufficient }\end{array}$ & 5 & 5 & 5 & 5 & 5 & 25 \\
\hline \multirow[t]{2}{*}{5} & $\begin{array}{l}\text { Music can support competition and } \\
\text { concentration }\end{array}$ & 5 & 5 & 5 & 5 & 5 & 25 \\
\hline & & & & & \multicolumn{2}{|c|}{ Average } & 24.6 \\
\hline
\end{tabular}

The criteria and limit values of development testing were determined (see Table 9).

Table 9. The criteria and limit values of development testing

\begin{tabular}{lll}
\multicolumn{1}{c}{ Development testing } & \multicolumn{2}{c}{ The criteria and limit values of language } \\
\hline The max score of each item: 5 & Very good & $\mathrm{X}>19.95$ \\
The min score of each item: 1 & Good & $16.65<\mathrm{X} \leq 19.95$ \\
Number of item: 5 & Enough & $13.35<\mathrm{X} \leq 16.65$ \\
Ideal average $=\frac{25+5}{2}=15$ & Less & $10.05<\mathrm{X} \leq 13.35$ \\
Standard deviation $=\frac{25-5}{6}=3.3$ & Very less & $\mathrm{X} \leq 10.05$ \\
& & \\
\hline
\end{tabular}

Overall, the result of development testing gots very good criteria (see Table 10). However, there was a less than optimal score on the "easy to use" component, because the ability to access the internet varies depending on the cellular internet provider of each student. In addition, the weakness of this linear program online game was the graphics were not clearly visible.

Table 10. Summary of development testing results

\begin{tabular}{clcc}
\hline No & Components & Average & Criteria \\
\hline 1 & Game online & 24.4 & Very good \\
2 & Appearance & 24.6 & Very good \\
\hline
\end{tabular}

\section{Experiment Testing}

After the Kahoot is implemented, students then filled out 30 statements on a questionnaire to find out their responses to the Kahoot online learning game that has been developed. This questionnaire aims to determine the practicality of Kahoot online learning games. The questionnaire results are presented in Table 11. 
Table 11. Student questionnaire results

\begin{tabular}{|c|c|c|c|c|c|c|}
\hline No & Aspect & Item & \multicolumn{2}{|c|}{ Practicality Grade } & $\bar{x}$ & Category \\
\hline \multirow[t]{5}{*}{1} & Content & $1-8$ & Very good & $X>67.35$ & 68.3 & Very Good \\
\hline & & & Good & $65.18<X \leq 67.35$ & & \\
\hline & & & Enough & $63.01<X \leq 65.18$ & & \\
\hline & & & Less & $60.84<X \leq 63.01$ & & \\
\hline & & & Very less & $X \leq 60.84$ & & \\
\hline \multirow[t]{5}{*}{2} & Learning & $9-14$ & Very good & $X>72.83$ & 72.85 & Very good \\
\hline & & & Good & $65.83<\mathrm{X} \leq 72.83$ & & \\
\hline & & & Enough & $58.83<X \leq 65.83$ & & \\
\hline & & & Less & $51.83<X \leq 58.83$ & & \\
\hline & & & Very less & $X \leq 51.83$ & & \\
\hline \multirow[t]{5}{*}{3} & Technical & $15-21$ & Very good & $X>69.18$ & 69.8 & Very good \\
\hline & & & Good & $63.63<X \leq 69.18$ & & \\
\hline & & & Enough & $58.08<X \leq 63.63$ & & \\
\hline & & & Less & $52.53<\mathrm{X} \leq 58.08$ & & \\
\hline & & & Very less & $X \leq 52.53$ & & \\
\hline \multirow[t]{5}{*}{4} & Overall & $22-30$ & Very good & $X>67.27$ & 67.32 & Very good \\
\hline & evaluation & & Good & $63.54<X \leq 67.27$ & & \\
\hline & & & Enough & $59.8<\mathrm{X} \leq 63.54$ & & \\
\hline & & & Less & $56.06<X \leq 59.8$ & & \\
\hline & & & Very less & $X \leq 56.06$ & & \\
\hline
\end{tabular}

All aspects of the assessment were "Very Good" category, it can be concluded that the online learning game is practical for use in learning. Media can be accessed and used by students easily without expensive costs. After the students have finished working on 10 questions on the Kahoot, a summary of the student's work can be seen immediately. From the results of the summary analysis, the level of difficulty of each question item can be determined (see Table 12).

Table 12. Results of test analysis

\begin{tabular}{cccc}
\hline Number & $\begin{array}{c}\text { The number of students } \\
\text { who answered correctly }\end{array}$ & $\begin{array}{c}\text { Percentage of } \\
\text { students who } \\
\text { answered correctly }\end{array}$ & Test difficulty level \\
\hline 1 & 18 & 64.29 & easy \\
2 & 13 & 46.43 & easy \\
3 & 18 & 64.29 & easy \\
4 & 15 & 53.57 & moderate \\
5 & 14 & 50 & moderate \\
6 & 21 & 75 & easy \\
7 & 14 & 50 & moderate \\
8 & 8 & 25 & difficult \\
9 & 10 & 35.71 & difficult \\
10 & 22 & 75 & easy \\
\hline
\end{tabular}

The scores obtained by the students were then converted into letter grades according to the university's academic guidelines (see Table 13). 
Table 13. Conversion of learning outcomes

\begin{tabular}{cccc}
\hline Interval class & Letter grades & Score & Category \\
\hline $90-100$ & $\mathrm{~A}$ & 4.00 & Very excellent \\
$80-89$ & $\mathrm{~A}-$ & 3.80 & Excellent \\
$75-79$ & $\mathrm{~B}+$ & 3.30 & Very good \\
$68-74$ & $\mathrm{~B}$ & 3.00 & Good \\
$64-67$ & $\mathrm{~B}-$ & 2.80 & Pretty good \\
$60-63$ & $\mathrm{C}+$ & 2.30 & Enough \\
$56-59$ & $\mathrm{C}$ & 2.00 & Not enough \\
$40-55$ & $\mathrm{D}$ & 1.00 & Less \\
$0-39$ & $\mathrm{E}$ & 0 & Very less \\
\hline
\end{tabular}

Student scores obtained from the application of the Kahoot online learning game are shown in Table 14.

Table 14. Student score

\begin{tabular}{|c|c|c|c|c|c|c|c|c|c|}
\hline No & Name & Correct & Score & $\begin{array}{l}\text { Letter } \\
\text { grades }\end{array}$ & No & Name & Correct & Score & $\begin{array}{l}\text { Letter } \\
\text { grades }\end{array}$ \\
\hline 1 & $\mathrm{~A}$ & 9 & 90 & $\mathrm{~A}$ & 15 & $\mathrm{O}$ & 7 & 70 & $\mathrm{~B}$ \\
\hline 2 & B & 9 & 90 & A & 16 & $\mathrm{P}$ & 7 & 70 & B \\
\hline 3 & $\mathrm{C}$ & 9 & 90 & A & 17 & Q & 7 & 70 & B \\
\hline 4 & $\mathrm{D}$ & 9 & 90 & A & 18 & $\mathrm{R}$ & 7 & 70 & B \\
\hline 5 & $\mathrm{E}$ & 8 & 80 & A- & 19 & S & 7 & 70 & B \\
\hline 6 & $\mathrm{~F}$ & 8 & 80 & A- & 20 & $\mathrm{~T}$ & 7 & 70 & B \\
\hline 7 & $\mathrm{G}$ & 8 & 80 & A- & 21 & $\mathrm{U}$ & 6 & 60 & $\mathrm{C}+$ \\
\hline 8 & $\mathrm{H}$ & 8 & 80 & A- & 22 & $\mathrm{~V}$ & 6 & 60 & $\mathrm{C}+$ \\
\hline 9 & I & 8 & 80 & A- & 23 & $\mathrm{~W}$ & 6 & 60 & $\mathrm{C}+$ \\
\hline 10 & $\mathrm{~J}$ & 8 & 80 & A- & 24 & $X$ & 6 & 60 & $\mathrm{C}+$ \\
\hline 11 & K & 8 & 80 & A- & 25 & Y & 5 & 50 & $\mathrm{D}$ \\
\hline 12 & $\mathrm{~L}$ & 7 & 70 & B & 26 & $\mathrm{Z}$ & 5 & 50 & $\mathrm{D}$ \\
\hline 13 & M & 7 & 70 & B & 27 & AA & 4 & 40 & $\mathrm{D}$ \\
\hline 14 & $\mathrm{~N}$ & 7 & 70 & B & 28 & $\mathrm{AB}$ & 4 & 40 & $\mathrm{D}$ \\
\hline
\end{tabular}

\subsection{Discussion}

The teaching-learning process is an important element in education, it includes the planning, implementation and assessment processes. Assessment refers to the process of observing the changes in the lives of the people (Çalışkan \& Kaşıkçı, 2010). During a pandemic, the right way to assess is to do a digital assessment. Digital assessments provide instant feedback and can be used to conduct individual or group assessments in a competitive environment (Yilmaz \& Baydas, 2017). So, digital assessment in education is important in terms of feedback and control of learning.

One of the digital assessments that can be used in learning, especially in learning mathematics is Kahoot!. The Kahoot! is a free online game application that can be used in every learning session to increase student participation and can be used as a formative assessment. Based on the results of development testing, it was concluded that Kahoot! easy to apply in learning because it does not require special training for students and can be easily accessed via a smartphone or PC (Plump \& LaRosa, 2017). The set time duration can increase the speed and accuracy in answering questions. The points earned by students are 
determined by how quickly students respond to questions as well as to answer question correctly. Kahoot! can be used to increase students' concentration during the course, especially when their concentration starts to decrease after the first ten minutes. In this study, Kahoot! proven to increase student interest in linear program lectures. They are motivated to attend lectures by communicating with others to exchange information about the subject.

In terms of appearance, Kahoot! can attract students' attention because of Kahoot! equipped with features that support the learning process. During the quiz, there is a music feature that can increase the enthusiasm of students in competing. In each quiz, Kahoot comes with customizable response times. When the time was up, a voice sounded and the names of the top 5 students were displayed on the board (Bawa, 2019; ÇETIN, 2018). Quiz featured on Kahoot! can vary, it can be in the form of quizzes, discussions or questionnaire, so that students do not get bored easily with the monotonous form of questions. In this study, the researcher used multiple choice questions and true-false questions with a sequence of questions adjusted to the level of difficulty.

Based on the results of the test analysis, it is known that students who use Kahoot! in learning activities achieve good grades in exams. It means that the Kahoot! application had the potential to improve and develop the high scores in exams. Our outcomes show that Kahoot! motivated students to be engaged the knowledge and encourage interaction in the classroom. Student stated that Kahoot! had a positive impact on their knowledge and skills. Features on Kahoot! which can increase attention and student involvement really supports students in learning.

\section{CONCLUSION}

This study has achieved the expected goal: producing valid, practical, and effective online learning games for linear program subjects. Validity is seen from the results of expert validation. Overall from the results of expert validation, it can be said that this product was very good or feasible to use. Practicality of this product is seen from the results of development testing and experiment testing. It show that the student's assessment of the product being developed was also very good or practical for use in learning. Effectiveness is obtained from student scores at the end of the game. Students who achieve a minimum score of $\mathrm{C}$ were $85.71 \%$. The linear program online learning game is said to be effective if the overall score obtained by students who reaches a minimum value of $\mathrm{C}$ is at least $75 \%$. It can be concluded that the linear program online learning game was effectively used in learning (Apsari \& Rizki, 2018; Ariawan et al., 2017).

Based on the results of the study it can be concluded that the development of Kahoot! meet the criteria of validity, practicality, and effectiveness. By the results of the validity test, the development of Kahoot! it has very good criteria in terms of content, construction, and language. Kahoot! also meet practical requirements in terms of content, technical learning, and overall evaluation. It means that Kahoot! easy to read, can present pictures/graphics clearly, enough time for students to answer the questions, the music features of Kahoot! can support competition and concentration, and the form of the questions presented is appropriate and adjusted to the level of difficulty of the questions. Application of Kahoot! also able to support students to achieve good scores on tests. Based on the results of the study, it is recommended that teachers can use creative learning media that utilize technology so that students become accustomed to using computers or laptops and smartphone not only to play game but also enrich their insights. The use of educational games in the classroom can also minimize interference, so as to improve the quality of learning. 


\section{REFERENCES}

Aleksić, V., Ivanović, M., Budimac, Z., \& Popescu, E. (2016). Commercial off-the-shelf games as learning media Proceedings of the 17th International Conference on Computer Systems and Technologies 2016, Palermo, Italy. https://doi.org/10.1145/2983468.2983493

Apsari, P. N., \& Rizki, S. (2018). Media pembelajaran matematika berbasis android pada materi program linear [Android-based mathematics learning media on linear programming material]. AKSIOMA: Jurnal Program Studi Pendidikan Matematika, 7(1), 161-170. https://doi.org/10.24127/ajpm.v7i1.1357

Ariawan, B. (2015). Menyelesaikan permasalahan program linear menggunakan Geogebra. In Prosiding Seminar Nasional Teknologi Pendidikan.

Ariawan, B., Muhsetyo, G., \& Qohar, A. (2017). Pengembangan edutainment multimedia untuk meningkatkan minat dan hasil belajar program linier siswa SMK. Jurnal Pendidikan: Teori, Penelitian, dan Pengembangan, 2(6), 780-789.

Bawa, P. (2019). Using Kahoot to inspire. Journal of Educational Technology Systems, 47(3), 373-390. https://doi.org/10.1177/0047239518804173

Becker, K. (2007). Digital game-based learning once removed: Teaching teachers. British Journal of Educational Technology, 38(3), 478-488. https://doi.org/10.1111/j.14678535.2007.00711.x

Çalışkan, H., \& Kaşıkçı, Y. (2010). The application of traditional and alternative assessment and evaluation tools by teachers in social studies. Procedia - Social and Behavioral Sciences, 2(2), 4152-4156. https://doi.org/10.1016/j.sbspro.2010.03.656

ÇETIN, H. S. (2018). Implementation of the digital assessment tool Kahoot in elementary school. International Technology and Education Journal, 2(1), 9-20.

Ding, D., Guan, C., \& Yu, Y. (2017). Game-based learning in tertiary education: A new learning experience for the generation Z. International Journal of Information and Education Technology, 7(2), 148-152. https://doi.org/10.18178/ijiet.2017.7.2.857

Ekanayake, S. Y., \& Wishart, J. (2014). Mobile phone images and video in science teaching and learning. Learning, Media and Technology, 39(2), 229-249. https://doi.org/10.1080/17439884.2013.825628

Ganyaupfu, E. M. (2013). Teaching methods and students' academic performance. International Journal of Humanities and Social Science Invention, 2(9), 29-35.

Godwin-Jones, R. (2011). Mobile apps for language learning. Language learning \& technology, 15(2), 2-11.

Hidayat, R. (2018). Game-based learning: Academic games sebagai metode penunjang pembelajaran kewirausahaan. Buletin Psikologi, 26(2), 71-85. https://doi.org/10.22146/buletinpsikologi.30988

Hughes, J. (2004). Technology learning principles for preservice and in-service teacher education. Contemporary Issues in Technology and Teacher Education, 4(3), 345362.

Kalyani, D., \& Rajasekaran, K. (2018). Innovative teaching and learning. Journal of applied and advanced research, 3(1), 23-25. https://doi.org/10.21839/jaar.2018.v3is1.162 
Pivec, M., \& Kearney, P. (2007). Games for learning and learning from games. Informatica, $31(4)$.

Plump, C. M., \& LaRosa, J. (2017). Using Kahoot! in the classroom to create engagement and active Learning: A game-based technology solution for elearning novices. Management Teaching Review, 2(2), 151-158. https://doi.org/10.1177/2379298116689783

Saparwadi, L., \& Aini, Q. (2016). Identifikasi permasalahan pembelajaran mahasiswa pendidikan matematika pada mata kuliah program linear: Studi kasus pada program studi pendidikan Matematika. Jurnal Tatsqif, 14(1), 33-48. https://doi.org/10.20414/jtq.v14i1.20

Wahid, A. H., Najiburrahman, Rahman, K., Faiz, Qodriyah, K., Hambali, El Iq Bali, M. M., Baharun, H., \& Muali, C. (2020). Effectiveness of android-based mathematics learning media application on student learning achievement. Journal of Physics: Conference Series, 1594(1), 012047. https://doi.org/10.1088/1742$6596 / 1594 / 1 / 012047$

Wahyudi, W., Ambarwati, M., \& Indarini, E. (2019). Development of web game learning materials for primary school students. Infinity Journal, 8(2), 199-208. https://doi.org/10.22460/infinity.v8i2.p199-208

Wardani, D. K., Martono, T., Pratomo, L. C., Rusydi, D. S., \& Kusuma, D. H. (2018). Online learning in higher education to encourage critical thinking skills in the 21 st century. International Journal of Educational Research Review, 4(2), 146-153. https://doi.org/10.24331/ijere.517973

Wijaya, T. T. (2020). How chinese students learn mathematics during the coronavirus pandemic. IJERI: International Journal of Educational Research and Innovation, 15, 1-16. https://doi.org/10.46661/ijeri.4950

Yilmaz, R. M., \& Baydas, O. (2017). An examination of undergraduates' metacognitive strategies in pre-class asynchronous activity in a flipped classroom. Educational Technology Research and Development, 65(6), 1547-1567. https://doi.org/10.1007/s11423-017-9534-1

Yu, F., \& Conway, A. (2012). Mobile/smartphone use in higher education. Proceedings of the 2012 Southwest Decision Sciences Institute, 831-839. 